\section{(6) OPEN ACCESS}

\title{
Sexual behaviour, structural vulnerabilities and HIV prevalence among female sex workers in Pakistan
}

\author{
Sharmistha Mishra, ${ }_{1}^{1}$ Laura H Thompson, ${ }^{2}$ Altaf Sonia, ${ }^{3}$ Nosheen Khalid, ${ }^{3}$ \\ Faran Emmanuel, ${ }^{2,3}$ James $\mathrm{F}$ Blanchard ${ }^{2}$
}

1 Department of Infectious Disease Epidemiology, Imperial College London, London, UK ${ }^{2}$ Centre for Global Public Health, Department of Community Health Sciences, University of Manitoba, Winnipeg, Canada

${ }^{3}$ Canada-Pakistan HIV/AIDS

Surveillance Project, Islamabad, Pakistan

\section{Correspondence to} Dr. James F Blanchard, Centre for Global Public Health, Department of Community Health Sciences, University of Manitoba, R070-771 McDermot Avenue, Winnipeg, MB, R3E 0T6, Canada; james_blanchard@umanitoba. ca

Received 25 July 2012 Revised 26 November 2012 Accepted 31 December 2012 Published Online First 14 February 2013

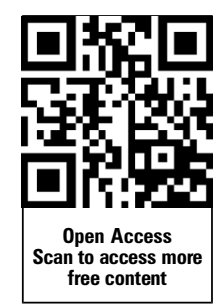

To cite: Mishra $\mathrm{S}$ Thompson LH, Sonia A, et al. Sex Transm Infect 2013;89:ii34-ii42.

\section{ABSTRACT}

Background We sought to describe differences in individual and structural vulnerabilities faced by female sex workers (FSWs) in Pakistan between 2006 and 2011, and to characterise risk factors for inconsistent condom use and HIV prevalence in this population. Methods To describe differences in vulnerabilities, we analysed behavioural data from serial cross-sectional surveys conducted across nine cities in 2006 and 2011. Using data from 12 cities in 2011, we used logistic regression to characterise risk factors for (a) inconsistent condom use in the past month ( $\mathrm{N}=6987)$, and (b) HIV $(\mathrm{N}=4301)$.

Results Compared to FSWs in 2006, FSWs in 2011 were significantly more likely to solicit clients via cell phones, and to report a larger client volume and anal sex with clients, but also consistent condom use with clients (30.0\% vs $23.6 \%$ in 2006). In 2011 , independent risk factors for inconsistent condom use with clients included: recent sexual violence, recent sex with a person who injects drugs, and absence of programme exposure. HIV prevalence was $0.63 \%$ (95\% $\mathrm{Cl} 0.43 \%$ to $0.92 \%$ ) in 2011 , and was associated with a recent history of injection drug use and absence of programme exposure.

Conclusions While condom use with clients was higher in 2011, protective behaviours remained low and vulnerabilities related to sex work may have risen. HIV is emerging in this population and an adaptive HIV prevention programme that addresses different vulnerabilities and the intersection of sexual networks with injection drug use is needed.

\section{INTRODUCTION}

Female sex work has a long history in Pakistan. Traditionally practiced by dancers in the royal court, sex work moved into brothels within 'red light' districts under British rule and through national independence. ${ }^{1} 2$ The industry then dispersed into clandestine sex work in residential areas after the first military leadership began in the 1970s. ${ }^{1}{ }^{2}$ Although changes in the organisation of female sex work $^{34}$ and male circumcision ${ }^{5}$ likely play important roles in the emergence and persistence of HIV among female sex workers (FSWs), individual and structural vulnerabilities within a regional context are also important. An understanding of sexual behaviour and partnerships, ${ }^{6-8}$ the practice of sex work $^{9}$ and experience of sexual violence ${ }^{1011}$ alongside HIV prevalence among FSWs is required to inform and strategically design HIV prevention programmes.

There is considerable heterogeneity in the practice of sex work ('sex work typology') between and within cities in Pakistan. ${ }^{12}$ FSWs who solicit clients in public places are classified as street-based FSWs, and are differentiated from FSWs who also solicit alms (FSWs who 'beg' for money in addition to exchanging sex for money). Most FSWs entertain clients at the sex worker's home (home-based FSWs). ${ }^{3}{ }^{4}$ Others live and work in brothels, a fixed location often owned and operated by madams and situated in neighbourhoods associated with sex work ('red light' districts). ${ }^{3}{ }^{4}$ Kothikhanas (KK) are venues rented by madams or network operators where a small number of FSWs live and entertain clients. ${ }^{3}$ In contrast to brothels, KKs are situated in residential neighbourhoods and are clandestine operations that often shift locations due to insecurity and fear of recrimination. ${ }^{3}{ }^{4}$ Home- and KK-based FSWs are particularly hidden and difficult to reach. As a result, their individual and structural vulnerabilities may differ from those of other FSWs. Within all typologies, the use of cell phones is increasing as a means of soliciting clients. ${ }^{13}$ Network operators (pimps, madams) and clients share FSWs' phone numbers with clients or potential clients, who in turn, reach FSWs via cell phones.

A respondent-driven sample of $730 \mathrm{FSWs}$ in Lahore found that $0.7 \%$ of FSWs were living with HIV/AIDS in 2007. ${ }^{7}$ Consistent ('always') condom use with clients was reported by $65 \%$ of FSWs, but only 19\% had heard of HIV. ${ }^{7}$ A 2003 study from Lahore and Karachi documented that $14 \%-20 \%$ of FSWs formed sexual partnerships with men who injected drugs (injection drug users, IDUs), suggesting the potential for the emergence of HIV among FSWs as a result of HIV infection in their IDU partners. ${ }^{8}$ Surveillance reports from 2007 revealed that across Pakistan, 22\% of IDUs purchased sex from women. ${ }^{14}$ Therefore, combined with low levels of condom use in the context of increasingly clandestine sex work, the introduction of HIV via FSWIDU sexual partnerships may lead to sustained HIV transmission among FSWs and clients. Yet the timing of these findings also offers the opportunity for early intervention to avert a sustained HIV epidemic among FSWs.

In 2005, Pakistan's National and Provincial AIDS Control Programs introduced HIV prevention interventions to key populations through public-private partnerships. ${ }^{8}$ As part of the prevention programmes, second generation HIV surveillance among FSWs was conducted via serial cross-sectional integrated biological and behavioural surveys (IBBS). Using two rounds of IBBS, we sought to examine differences in individual and structural vulnerabilities and HIV prevalence among FSWs between 2006 and 2011, and to 
characterise risk factors associated with inconsistent condom use with clients and HIV prevalence in 2011.

\section{METHODS}

\section{Study setting and data collection}

To describe differences in individual and structural vulnerabilities between IBBS rounds, we restricted our analysis to the nine cities included in the 2006 and 2011 surveys: Lahore, Karachi, Quetta, Peshawar, Multan, Faisalabad, Sargodha, Sukkur and Larkana. For analysis of 2011 data alone, all 12 cities surveyed in 2011 were examined: in addition to the above nine cities, the cities of Haripur, Rawalpindi and Dera Ghazi Khan were included.

Mapping and enumeration conducted in 2006 and 2011 estimated that 49037 and 73675 women, respectively, were actively engaged in commercial sex in the nine cities selected for comparison between survey rounds. ${ }^{15}$ Compared with 2006, the 2011 enumeration included additional information from network operators (pimps, madams). ${ }^{15}$ In the nine cities, 242 and 258 clusters (neighborhoods or 'zones') were enumerated in 2006 and 2011, respectively. ${ }^{15}$ Estimated FSW population size, and the number and size of clusters increased between rounds, representing dynamism in the location and nature of sex work, an increase in sex work, and improved mapping and enumeration in $2011 .^{15}$ In 2011, it was estimated that 81717 FSWs (across 310 clusters) were working in the 12 cities selected for surveillance. ${ }^{15}$

Sex work was defined as the provision of sex to a man in exchange for money or other financial benefits, and the survey was restricted to FSWs 15 years of age and older. The sample size for each city was calculated to detect a $15 \%$ difference in condom use between the baseline and 2011 surveys, with $80 \%$ power, an $\alpha$ error of $5 \%$ and a design effect of 2, assuming a baseline value of condom use 'at last sex' with commercial clients of $45 \%$, and $10 \%$ non-response. ${ }^{13}$ The power analyses were conducted at the individual level, but the sample size accounted for the design effect. The sample size for in each city ranged between 211 and 377 participants. ${ }^{13}$ After stratifying by typology, participants were recruited via conventional cluster sampling ${ }^{16}$ (probability proportional to enumerated cluster size) and random sampling within clusters (proportional to cluster size) for the following typologies: home-based, street-based, FSWs who also solicit alms, and KK-based FSWs. ${ }^{13}$ Brothel-based FSWs were selected via systematic random sampling of enumerated brothelbased FSWs. ${ }^{13}$ Sampling was conducted independently for each round of the IBBS in an effort to obtain representative samples at both time points. In the nine cities compared between 2006 and 2011, 181 and 176 clusters are represented in the data, respectively. For the 12 cities examined for risk factors in 2011, 204 clusters are represented in the data. Mapping reports, with estimates of FSW population size, and information on surveillance sampling methodology (including sample size for each city) are available online at http://www.nacp.gov.pk/surveillance_and_ research/.

After obtaining informed consent, trained interviewers administered a face-to-face structured questionnaire in the local language (Urdu). The questionnaire was designed in English, and included information on demographic characteristics, sex work and migration, sexual behaviour, access to intervention programmes, and knowledge of sexually transmitted infections (STIs)/HIV. Interviews were conducted at the brothels for brothel-based FSWs and at a central field office for all other participants. The questionnaire is available online at http:// www.nacp.gov.pk/library/publications/HASP/IBBS\%20Manual\% 20English.pdf.
Capillary dried blood spots (DBS) were collected by interviewers. The sample was immediately dried and stored at room temperature before weekly transport to the reference laboratories for testing (Sindh Institute of Urology and Transplantation, Karachi and Armed Forces Institute of Pathology, Rawalpindi). The DBS were screened using an enzyme immunoassay (HIV Genetic Systems rLAV ELISA/EIA, Bio-Rad, USA), with positive tests confirmed in duplicate with an alternative enzyme immunoassay (Vironostika HIV Uni-Form II EIA, Biomerieux, The Netherlands). In the case of indeterminate results with either enzyme immunoassay, the Genetic Systems HIV-1 Western Blot (Bio-Rad) was used to resolve the discrepancy and provide a final result. All participants were referred for voluntary counselling and testing for HIV, and given information on HIV prevention and local programme services for FSWs.

\section{Data analysis}

Data were double-entered using Microsoft Access and statistical analysis was performed using STATA V.11.0. Successive rounds of surveys were not linked via participant information, and therefore it was not possible to determine which individuals participated in both the 2006 and 2011 rounds of data collection. The cities of Multan, Faisalabad, Sargodha, Rawalpindi and Dera Ghazi Khan were combined and collectively referred to as 'other Punjab', while Sukkur and Larkana were combined and collectively referred to as 'other Sindh'. Data collected in Lahore, Karachi, Quetta and Peshawar were examined separately for each city.

We reported descriptive statistics using measures of central tendency. Bivariate analyses of sociodemographic covariates, the practice of sex work, sexual behaviour and partnerships, and structural vulnerabilities between the two rounds were examined with parametric and non-parametric tests of association. Adjusted analysis was conducted for three outcomes (inconsistent condom use with clients in the past month, inconsistent condom use with nonclients in the past month, and HIV prevalence) using multivariate logistic regression. Inconsistent condom use was defined as 'sometimes' or 'never' condom use in the month preceding the survey. Multiple imputation was conducted to resolve missing values for variables that were examined as covariates for these three outcomes. For HIV prevalence, only districts in which there was at least one case of HIV were included in the adjusted analysis. Results were corrected for within cluster homogeneity.

The institutional review boards of HOPE International in Pakistan and the Public Health Agency of Canada provided ethics approval for the study. Monetary compensation was provided to participants for their time in accordance with suggestions and discussions with each local FSW community during study planning.

\section{RESULTS}

\section{Study population}

The study population comprised 3647 FSWs in 2006 and 3340 FSWs in 2011 for the nine cities included in both rounds of data collection. The total study population in 2011 comprised 4301 respondents surveyed in 12 cities. Table 1 highlights the sociodemographic characteristics of participants for the nine cities included in both years. Over half of FSWs were married at the time of the surveys $(59.8 \%$ and $57.0 \%$ in 2006 and 2011 , respectively). Participants in 2006 were slightly older (median age 27 years) compared to participants in 2011 (median age 26 years, $p=0.02$ ), but the fraction of FSWs under age 20 was not significantly different $(9.7 \%$ in both rounds, $\mathrm{p}>0.1)$. Literacy was lower among participants in $2011(48.7 \%$ vs $57.6 \%$ in $2006, \mathrm{p}=0.002$ ), as was the fraction of FSWs who 
Table 1 Sociodemographic characteristics of female sex workers in Pakistan in 2006 and 2011 for the nine cities included in both rounds of the IBBS (N=6987)

\begin{tabular}{|c|c|c|c|c|c|c|c|c|c|c|c|c|c|c|}
\hline & \multicolumn{2}{|l|}{ Lahore } & \multicolumn{2}{|l|}{ Other Punjab } & \multicolumn{2}{|l|}{ Karachi } & \multicolumn{2}{|l|}{ Other Sindh } & \multicolumn{2}{|l|}{ Quetta } & \multicolumn{2}{|l|}{ Peshawar } & \multicolumn{2}{|l|}{ All cities* } \\
\hline & $\begin{array}{l}2006 \\
N=425\end{array}$ & $\begin{array}{l}2011 \\
N=375\end{array}$ & $\begin{array}{l}2006 \\
N=1200\end{array}$ & $\begin{array}{l}2011 \\
N=1126\end{array}$ & $\begin{array}{l}2006 \\
N=403\end{array}$ & $\begin{array}{l}2011 \\
\mathrm{~N}=377\end{array}$ & $\begin{array}{l}2006 \\
\mathrm{~N}=800\end{array}$ & $\begin{array}{l}2011 \\
N=750\end{array}$ & $\begin{array}{l}2006 \\
\mathrm{~N}=396\end{array}$ & $\begin{array}{l}2011 \\
\mathrm{~N}=345\end{array}$ & $\begin{array}{l}2006 \\
N=423\end{array}$ & $\begin{array}{l}2011 \\
N=367\end{array}$ & $\begin{array}{l}2006 \\
N=3647\end{array}$ & $\begin{array}{l}2011 \\
N=3340\end{array}$ \\
\hline Median age (range) & $\begin{array}{c}26 \\
(15-45)\end{array}$ & $\begin{array}{c}27 \\
(15-45)\end{array}$ & $\begin{array}{c}26 \\
(15-45)\end{array}$ & $\begin{array}{c}27 \\
(16-45)\end{array}$ & $\begin{array}{c}28 \\
(15-45)\end{array}$ & $\stackrel{26}{(15-48) \dagger}$ & $\begin{array}{c}28 \\
(16-45)\end{array}$ & $\begin{array}{c}25 \\
(16-49) \dagger\end{array}$ & $\begin{array}{c}28 \\
(16-45)\end{array}$ & $\stackrel{26}{(16-40) \dagger}$ & $\begin{array}{l}25 \\
(15-45)\end{array}$ & $\stackrel{27}{(16-43) \dagger}$ & $\begin{array}{c}27 \\
(15-45)\end{array}$ & $\stackrel{26}{(15-49) \dagger}$ \\
\hline $\begin{array}{l}\text { \% Illiterate } \\
(95 \% \mathrm{Cl})\end{array}$ & $\begin{array}{l}40.2 \\
\text { (32.7 to } 48.3 \text { ) }\end{array}$ & $\begin{array}{l}43.5 \\
\text { (36.5 to } 50.7)\end{array}$ & $\begin{array}{l}43.9 \\
\text { (37.0 to } 51.1 \text { ) }\end{array}$ & $\begin{array}{l}43.1 \\
\text { (38.1 to } 48.4 \text { ) }\end{array}$ & $\begin{array}{l}42.9 \\
\text { (37.2 to } 48.9)\end{array}$ & $\begin{array}{l}53.9 \\
(46.8 \text { to } 60.7) \dagger\end{array}$ & $\begin{array}{l}28.8 \\
\text { (20.6 to } 38.5)\end{array}$ & $\begin{array}{l}54.4 \\
(44.8 \text { to } 61.7) \dagger\end{array}$ & $\begin{array}{l}74.2 \\
\text { (66.3 to } 80.8)\end{array}$ & $\begin{array}{l}75.5 \\
\text { (70.5 to } 79.9)\end{array}$ & $\begin{array}{l}36.0 \\
\text { (28.3 to } 44.5)\end{array}$ & $\begin{array}{l}55.0 \\
(48.7 \text { to } 61.2) \dagger\end{array}$ & $\begin{array}{l}42.4 \\
\text { (37.9 to } 47.1 \text { ) }\end{array}$ & $\begin{array}{l}51.3 \\
(48.6 \text { to } 54.0) \dagger\end{array}$ \\
\hline \multicolumn{15}{|l|}{$\begin{array}{l}\text { Marital status, \% } \\
(95 \% \text { CI) }\end{array}$} \\
\hline Unmarried & $\begin{array}{l}27.3 \\
\text { (22.2 to } 33.1 \text { ) }\end{array}$ & $\begin{array}{l}24.9 \\
\text { (18.7 to } 32.2 \text { ) }\end{array}$ & $\begin{array}{l}26.2 \\
\text { (21.2 to } 31.8)\end{array}$ & $\begin{array}{l}25.0 \\
\text { (21.0 to } 29.6 \text { ) }\end{array}$ & $\begin{array}{l}15.4 \\
\text { (11.1 to } 21.0)\end{array}$ & $\begin{array}{l}19.4 \\
\text { (14.6 to } 25.2)\end{array}$ & $\begin{array}{l}18.8 \\
\text { (13.8 to } 24.9)\end{array}$ & $\begin{array}{l}27.3 \\
\text { (20.6 to } 35.3 \text { ) }\end{array}$ & $\begin{array}{l}47.0 \\
\text { (40.3 to } 53.8 \text { ) }\end{array}$ & $\begin{array}{l}49.3 \\
\text { (44.9 to } 53.7)\end{array}$ & $\begin{array}{l}41.6 \\
\text { (36.3 to } 47.1 \text { ) }\end{array}$ & $\begin{array}{l}31.6 \\
\text { (25.8 to } 38.1)\end{array}$ & $\begin{array}{l}27.5 \\
\text { (24.6 to } 30.7 \text { ) }\end{array}$ & $\begin{array}{l}28.1 \\
\text { (25.0 to } 31.4 \text { ) }\end{array}$ \\
\hline Married & $\begin{array}{l}48.7 \\
\text { (43.0 to } 54.5 \text { ) }\end{array}$ & $\begin{array}{l}70.3 \\
\text { (62.5 to } 77.1 \text { ) }\end{array}$ & $\begin{array}{l}56.8 \\
\text { (52.7 to } 60.9)\end{array}$ & $\begin{array}{l}62.3 \\
\text { (58.8 to } 65.7 \text { ) }\end{array}$ & $\begin{array}{l}77.4 \\
\text { (71.6 to } 82.3 \text { ) }\end{array}$ & $\begin{array}{l}69.8 \\
\text { (64.6 to } 74.5)\end{array}$ & $\begin{array}{l}78.4 \\
\text { (72.0 to } 83.7 \text { ) }\end{array}$ & $\begin{array}{l}54.3 \\
\text { (42.8 to } 65.3 \text { ) }\end{array}$ & $\begin{array}{l}42.4 \\
\text { (36.0 to } 49.1 \text { ) }\end{array}$ & $\begin{array}{l}38.2 \\
\text { (32.0 to } 44.8)\end{array}$ & $\begin{array}{l}43.5 \\
\text { (37.7 to } 49.4 \text { ) }\end{array}$ & $\begin{array}{l}37.3 \\
\text { (33.2 to } 41.6 \text { ) }\end{array}$ & $\begin{array}{l}59.8 \\
\text { (55.9 to } 63.6)\end{array}$ & $\begin{array}{l}57.0 \\
\text { (53.3 to } 60.7 \text { ) }\end{array}$ \\
\hline Separated/ divorced/ widowed & $\begin{array}{l}24.0 \\
\text { (19.8 to } 28.8)\end{array}$ & $\begin{array}{l}4.8 \\
\text { (3.1 to } 7.4)+\end{array}$ & $\begin{array}{l}13.9 \\
(20.6)\end{array}$ & $\begin{array}{l}12.6 \\
(9.4 \text { to } 16.7)\end{array}$ & $\begin{array}{l}7.2 \\
\text { (4.7 to } 10.8)\end{array}$ & $\begin{array}{l}10.9 \\
(7.9 \text { to } 14.8)\end{array}$ & $\begin{array}{l}2.9 \\
\text { (1.3 to } 6.4)\end{array}$ & $\begin{array}{l}18.4 \\
(13.7 \text { to } 24.3)+\end{array}$ & $\begin{array}{l}10.6 \\
\text { (7.0 to } 15.7)\end{array}$ & $\begin{array}{l}12.5 \\
(9.1 \text { to } 17.0) \\
(\mathrm{N}=343)\end{array}$ & $\begin{array}{l}14.9 \\
\text { (11.5 to } 19.0)\end{array}$ & $\begin{array}{l}31.1 \\
(24.4 \text { to } 38.7) \dagger\end{array}$ & $\begin{array}{l}12.7 \\
\text { (10.7 to } 15.1)\end{array}$ & $\begin{array}{l}14.9 \\
(13.3 \text { to } 16.5) \\
(\mathrm{N}=3337)\end{array}$ \\
\hline \multicolumn{15}{|l|}{$\begin{array}{l}\text { Living arrangements, \% } \\
(95 \% \mathrm{CI})\end{array}$} \\
\hline Family home & $\begin{array}{l}82.8 \\
\text { (78.0 to } 86.8)\end{array}$ & $\begin{array}{l}82.6 \\
\text { (75.3 to } 88.1 \text { ) }\end{array}$ & $\begin{array}{l}81.8 \\
\text { (73.2 to } 88.0)\end{array}$ & $\begin{array}{l}78.3 \\
\text { (73.8 to } 82.3 \text { ) }\end{array}$ & $\begin{array}{l}80.4 \\
\text { (69.0 to } 88.3)\end{array}$ & $\begin{array}{l}90.6 \\
\text { (84.3 to } 94.6 \text { ) }\end{array}$ & $\begin{array}{l}78.8 \\
\text { (67.4 to } 86.9)\end{array}$ & $\begin{array}{l}90.1 \\
\text { (83.7 to } 94.2 \text { ) }\end{array}$ & $\begin{array}{l}83.8 \\
\text { (79.4 to } 87.3 \text { ) }\end{array}$ & $\begin{array}{l}82.6 \\
\text { (73.0 to } 89.2)\end{array}$ & $\begin{array}{l}88.4 \\
\text { (80.8 to } 93.3 \text { ) }\end{array}$ & $\begin{array}{l}73.5 \\
\text { (68.5 to } 77.9)\end{array}$ & $\begin{array}{l}82.1 \\
\text { (79.0 to } 84.8 \text { ) }\end{array}$ & $\begin{array}{l}82.9 \\
\text { (80.4 to } 85.2\end{array}$ \\
\hline Guest house & $\begin{array}{l}4.0 \\
\text { (1.9 to } 8.4)\end{array}$ & $\begin{array}{l}0.41 \\
(0 \text { to } 3.0)\end{array}$ & $\begin{array}{l}1.4 \\
(0.67 \text { to } 3.0)\end{array}$ & $\begin{array}{l}0.49 \\
(0.19 \text { to } 1.3)\end{array}$ & 0 & $\begin{array}{l}0.27 \\
(0 \text { to } 2.0)\end{array}$ & $\begin{array}{l}2.5 \\
\text { (0.52 to } 11.1)\end{array}$ & $\begin{array}{l}0.40 \\
(0 \text { to } 2.0)\end{array}$ & $\begin{array}{l}7.4 \\
\text { (4.2 to } 12.6)\end{array}$ & $\begin{array}{l}5.2 \\
\text { (2.9 to } 9.3)\end{array}$ & $\begin{array}{l}1.9 \\
\text { (0.71 to } 5.0)\end{array}$ & $\begin{array}{l}11.9 \\
\text { (8.8 to } 15.9 \text { ) }\end{array}$ & $\begin{array}{l}2.5 \\
\text { (1.7 to } 3.7)\end{array}$ & $\begin{array}{l}2.3 \\
\text { (1.7 to } 3.1)\end{array}$ \\
\hline KK/brothel & $\begin{array}{l}12.7 \\
(9.7 \text { to } 16.5)\end{array}$ & $\begin{array}{l}17.0 \\
(11.7 \text { to } 24.1)\end{array}$ & $\begin{array}{l}11.9 \\
\text { (8.3 to } 16.8)\end{array}$ & $\begin{array}{l}21.2 \\
\text { (17.2 to } 25.8)\end{array}$ & $\begin{array}{l}18.9 \\
(11.0 \text { to } 30.4)\end{array}$ & $\begin{array}{l}9.1 \\
\text { (5.1 to } 15.6)\end{array}$ & $\begin{array}{l}8.3 \\
\text { (4.0 to } 16.3)\end{array}$ & $\begin{array}{l}9.5 \\
\text { (5.8 to } 15.1)\end{array}$ & $\begin{array}{l}8.6 \\
\text { (6.4 to } 11.5)\end{array}$ & $\begin{array}{l}12.2 \\
\text { (5.7 to } 24.3)\end{array}$ & $\begin{array}{l}9.5 \\
\text { (4.7 to } 18.2)\end{array}$ & $\begin{array}{l}14.6 \\
\text { (10.8 to } 19.5)\end{array}$ & $\begin{array}{l}11.3 \\
\text { (9.2 to } 13.9)\end{array}$ & $\begin{array}{l}14.8 \\
(12.6 \text { to } 17.3)\end{array}$ \\
\hline Other & $\begin{array}{l}0.47 \\
(0.11 \text { to } 2.0)\end{array}$ & $\begin{array}{l}0 \dagger \\
(\mathrm{N}=241)\end{array}$ & $\begin{array}{l}4.9 \\
\text { (11.1 to } 19.2)\end{array}$ & $\begin{array}{c}0 \\
(N=1015)\end{array}$ & $\begin{array}{l}0.74 \\
(0.24 \text { to } 2.3)\end{array}$ & $\begin{array}{l}0+ \\
(\mathrm{N}=374)\end{array}$ & $\begin{array}{l}10.5 \\
\text { (3.0 to 31.1) }\end{array}$ & $\begin{array}{c}0 \\
(\mathrm{~N}=749)\end{array}$ & $\begin{array}{l}0.25 \\
(0 \text { to } 2.1) \\
(\mathrm{N}=394)\end{array}$ & $\begin{array}{c}0 \\
(\mathrm{~N}=327)\end{array}$ & $\begin{array}{l}0.24 \\
(0 \text { to } 1.8)\end{array}$ & $\begin{array}{l}0 \dagger \\
(\mathrm{N}=362)\end{array}$ & $\begin{array}{l}4.1 \\
(1.9 \text { to } 8.8) \\
(\mathrm{N}=3645)\end{array}$ & $\begin{array}{l}0 \dagger \\
(\mathrm{N}=3068)\end{array}$ \\
\hline $\begin{array}{l}\text { Non-local FSWs, \% from another city } \\
(95 \% \mathrm{Cl})\end{array}$ & $\begin{array}{l}33.7 \\
(27.8 \text { to } 40.1)\end{array}$ & $\begin{array}{l}12.5 \\
(9.7 \text { to } 16.1) \dagger\end{array}$ & $\begin{array}{l}19.0 \\
\text { (14.6 to } 24.4)\end{array}$ & $\begin{array}{l}13.5 \\
(9.0 \text { to } 19.9)\end{array}$ & $\begin{array}{l}48.1 \\
\text { (39.3 to } 57.1)\end{array}$ & $\begin{array}{l}33.7 \\
(28.7 \text { to } 39.1) \dagger\end{array}$ & $\begin{array}{l}17.3 \\
\text { (7.1 to } 36.3)\end{array}$ & $\begin{array}{l}6.8 \\
\text { (3.7 to 12.2) }\end{array}$ & $\begin{array}{l}23.5 \\
\text { (19 to } 28.5)\end{array}$ & $\begin{array}{l}29.6 \\
\text { (22.5 to } 37.7 \text { ) }\end{array}$ & $\begin{array}{l}30.7 \\
\text { (23.2 to } 39.4 \text { ) }\end{array}$ & $\begin{array}{l}15.3 \\
(11.2 \text { to } 20.4) \dagger\end{array}$ & $\begin{array}{l}25.4 \\
\text { (21.4 to } 29.8 \text { ) }\end{array}$ & $\begin{array}{l}16.0 \\
(12.8 \text { to } 19.8) \dagger\end{array}$ \\
\hline
\end{tabular}


lived in another city $(16.0 \%$ vs $25.4 \%$ in $2006, \mathrm{p}<0.001)$. Living arrangements varied across cities, with an overall higher fraction of FSWs living in kothikhanas and brothels in 2011 (except in Karachi). However, most FSWs (more than 70\%) lived in their family home.

\section{Practice of sex work}

Differences were observed in the practice of sex work between 2006 and 2011 in the nine cities for which a direct comparison could be made (table 2). Overall, FSWs surveyed in 2011 had started sex work earlier (median age 20 years) than FSWs working in 2006 (median age 22 years, $p=0.01$ ), but there was no significant difference between the fraction of FSWs who started sex work prior to age $15(4.3 \%$ vs $4.5 \%$ in 2006 and 2011, respectively, $\mathrm{p}>0.1$ ).

Among participants in the province of Punjab (including Lahore), there were more home-based FSWs and fewer streetbased FSWs in 2011 as compared with $2006(\mathrm{p}<0.001)$. A larger fraction of FSWs also reported two emerging typologies - as FSWs who solicit alms and sell sex on a part-time basis, and FSWs whose sole method of solicitation occurs via cell phones (ie, mobile operators). Compared with $4.1 \%$ of FSWs overall in $2006,5 \%$ (95\% CI $4.2 \%$ to $6.0 \%)$ and $10.4 \%(95 \%$ CI $9.1 \%$ to $11.8 \%$ ) of FSWs in 2011 were classified according to these two typologies: FSWs who solicit alms and mobile operators. In 2011, 29.4\% of FSWs primarily used cell phones to solicit clients, compared with $19.5 \%$ in 2006 ( $\mathrm{p}<0.001$; table 2), although a difference was not observed in Karachi or Quetta. The median income per FSW was also significantly higher in the second round, increasing from 9000 Pakistani rupees in 2006 to 17000 Pakistani rupees in $2011(\mathrm{p}<0.001)$. Of note, $85.9 \%(95 \%$ CI $83.1 \%$ to $88.5 \%)$ and $98.4 \%(95 \%$ CI $97.9 \%$ to $98.8 \%$ ) of FSWs in 2006 and 2011, respectively, earned an income greater than the average monthly income of females in Pakistan in 2006-2007 (5000 Pakistani rupees per month). ${ }^{17}$ The median number of clients per FSW in the last month was also higher in 2011 (25 in 2006 vs 50 in 2011, $\mathrm{p}<0.001$; table 2).

\section{Structural vulnerabilities, programme exposure and sexual behaviour}

As shown in table 2, a greater proportion of FSWs reported recent injection drug use $(1.8 \%$ vs $5.4 \%, \mathrm{p}<0.001)$, recent sex with an IDU (8.9 vs $16.0 \%, \mathrm{p}<0.001)$, recent sexual violence $(15.7 \%$ vs $22.4 \%, \mathrm{p}<0.001)$ and a recent history of police arrests in 2011 compared with $2006(7.7 \%$ vs $15.6 \%$, $\mathrm{p}<0.001)$. Overall, $10.3 \%$ of respondents were unaware of whether a partner injected drugs. More than half of FSWs in 2011 reported sharing sex work income with a mediator, their husband or the police, whereas in 2006, 17.4\% of FSWs reported income-sharing $(\mathrm{p}<0.001$; table 2$)$.

By 2011, 20.7\% (95\% CI $17.5 \%$ to $24.3 \%$ ) had accessed the HIV prevention programmes, a significant difference from the $2.1 \%$ (95\% CI $1.1 \%$ to $4.2 \%$ ) of FSWs who had contact with the programmes in 2006 ( $\mathrm{p}<0.001)$. By 2011, 75.6\% (95\% CI $72.2 \%$ to $78.7 \%$ ) of FSWs had heard of HIV/AIDS, a small increase from the $69.0 \%$ (95\% CI $66.3 \%$ to $72.0 \%, \mathrm{p}=0.001$ ) observed in 2006 .

In 2011, 30.0\% of FSWs reported 'always' condom use with clients in the previous month, compared with $23.6 \%$ of FSWs in $2006(\mathrm{p}=0.03)$. Similarly, self-reported 'always' condom use with non-paying partners was higher in 2011 (20.7\% vs 13.4\% in 2006). In 2011, half of FSWs reported at least one anal sex act in the previous month with clients (table 2). Both anal and oral sex with clients was less commonly reported in 2006 (table 2).

\section{Predictors of non-condom use and emergence of HIV}

In 2006, no cases of HIV were detected among study participants. In 2011, 25 cases of HIV were detected $(0.63 \%$, 95\% CI 0.43 to $0.92 \%)$. The distribution of HIV-positive respondents is shown in table 3 . As shown in table 4, after adjusting for region (in regions where at least one case of HIV was detected), programme exposure was protective with respect to HIV prevalence. Adjusting for region, a recent history of injecting drugs was associated with an increased risk of HIV. Caution is required when extrapolating further based on these two associations because of the small number of HIV-positive cases in this population.

Table 4 outlines the independent risk factors associated with inconsistent condom use with a client and the independent risk factors associated with inconsistent condom use with a nonpaying partner, in the month prior to the 2011 survey. After adjusting for regional variability, literacy, duration in sex work, solicitation without a mediator, sex with a non-paying partner in the previous month, sex or being unsure of having sex with an IDU, recent sexual violence and lack of programme exposure were independently associated with inconsistent condom use with clients in the past month (table 4). Among FSWs who reported sex with a non-paying partner in the previous month, women who could not read or write, with a larger client volume ( $\geq 60$ per month), recent experience of sexual violence, longer history of sex work and without previous programme access were least likely to report 'always' condom use with nonpaying partners after adjusting for the region in which they practiced sex work (table 4).

\section{DISCUSSION}

Understanding the practice of sex work and vulnerabilities that place FSWs at risk of HIV is the key to formulating and adapting a targeted HIV prevention programme. In Pakistan, we observed important differences in work-related vulnerabilities experienced by FSWs between two rounds of representative surveys, profiled FSWs least likely to report recent condom use, and documented the emergence of HIV among FSWs. We report the first cases of HIV among FSWs officially detected in Pakistan outside of Lahore, although a different sampling method was used in previous studies. ${ }^{78}$

We found differences in the practice of sex work between 2006 and 2011, with 29.4\% of participants using cell phones as their primary method of solicitation in 2011. The use of mobile technology has emerged as a major 'operator' in the business of sex work, ${ }^{18} 19$ and this study reveals that sex work in Pakistan is no exception. The extent to which mobile technology has changed the sexual networks of FSWs and clients, social networks between FSWs, and the visibility of FSWs to prevention programmes remains unknown. While the dissolution of the red light district in Goa, India resulted in a dispersion of sex work, ${ }^{20}$ it is unclear if cell phones are creating a similar effect in Asia, including Pakistan. The use of cell phones among FSWs also offers an opportunity to reach FSWs and form links with the prevention programmes, the health care team and peereducators. $^{21-23}$ Reported client volume and monthly income from sex work were higher in 2011. Although we do not interrogate this finding further in our study, the difference may be due in part to rising inflation in Pakistan. ${ }^{17} 24$

Differences in the sociodemographic profile of FSWs, the practice of sex work and HIV prevalence between 2006 and 
Table 2 Description of the practice of female sex work and related structural vulnerabilities in Pakistan in 2006 and 2011 for the nine cities included in both rounds of the IBBS (N=6987)

\begin{tabular}{|c|c|c|c|c|c|c|c|c|c|c|c|c|c|c|}
\hline & \multicolumn{2}{|l|}{ Lahore } & \multicolumn{2}{|l|}{ Other Punjab } & \multicolumn{2}{|l|}{ Karachi } & \multicolumn{2}{|c|}{ Other Sindh } & \multicolumn{2}{|l|}{ Quetta } & \multicolumn{2}{|l|}{ Peshawar } & \multicolumn{2}{|l|}{ All cities* } \\
\hline & $\begin{array}{l}2006 \\
N=425\end{array}$ & $\begin{array}{l}2011 \\
N=375\end{array}$ & $\begin{array}{l}2006 \\
N=1200\end{array}$ & $\begin{array}{l}2011 \\
N=1126\end{array}$ & $\begin{array}{l}2006 \\
N=403\end{array}$ & $\begin{array}{l}2011 \\
N=377\end{array}$ & $\begin{array}{l}2006 \\
N=800\end{array}$ & $\begin{array}{l}2011 \\
N=750\end{array}$ & $\begin{array}{l}2006 \\
N=396\end{array}$ & $\begin{array}{l}2011 \\
N=345\end{array}$ & $\begin{array}{l}2006 \\
N=423\end{array}$ & $\begin{array}{l}2011 \\
N=367\end{array}$ & $\begin{array}{l}2006 \\
N=3647\end{array}$ & $\begin{array}{l}2011 \\
N=3340\end{array}$ \\
\hline Age at sex work initiation, median (range) & $\begin{array}{l}22 \\
(6-43) \\
(N=422)\end{array}$ & $\begin{array}{l}21 \\
(11-42) \\
(N=374)\end{array}$ & $\begin{array}{l}21 \\
(8-41) \\
(\mathrm{N}=1197)\end{array}$ & $\begin{array}{l}21 \\
(8-41) \\
(\mathrm{N}=1120)\end{array}$ & $\begin{array}{l}22 \\
(10-44) \\
(N=399)\end{array}$ & $\begin{array}{l}21 \\
(10-46) \\
(N=376)\end{array}$ & $\begin{array}{l}20 \\
(12-40) \\
(\mathrm{N}=796)\end{array}$ & $\begin{array}{l}20 \\
(10-37) \dagger\end{array}$ & $\begin{array}{l}23 \\
(9-44) \\
(\mathrm{N}=309)\end{array}$ & $\begin{array}{l}19 \\
(7-30) \dagger \\
(\mathrm{N}=342)\end{array}$ & $\begin{array}{l}20 \\
(10-39) \\
(\mathrm{N}=415)\end{array}$ & $\begin{array}{l}23 \\
(15-41) \dagger \\
(\mathrm{N}=363)\end{array}$ & $\begin{array}{l}22 \\
(6-44) \\
(\mathrm{N}=3538)\end{array}$ & $\begin{array}{l}20 \\
(7-46) \dagger \\
(\mathrm{N}=3325)\end{array}$ \\
\hline \multicolumn{15}{|l|}{$\begin{array}{l}\text { Sex work typology, \% } \\
(95 \% \mathrm{Cl})\end{array}$} \\
\hline Home-based & $\begin{array}{l}12.2 \\
(7.5 \text { to } \\
19.4)\end{array}$ & $\begin{array}{l}43.7 \\
(33.8 \text { to } \\
54.2)\end{array}$ & $\begin{array}{l}41.1 \\
(34.8 \text { to } \\
47.6)\end{array}$ & $\begin{array}{l}48.3 \\
\text { (43.0 to } 53.7)\end{array}$ & $\begin{array}{l}17.4 \\
(10.4 \text { to } \\
27.7)\end{array}$ & $\begin{array}{l}35.0 \\
(24.7 \text { to } \\
47.0)\end{array}$ & $\begin{array}{l}41.5 \\
(19.2 \text { to } \\
67.9)\end{array}$ & $\begin{array}{l}60.3 \\
(49.7 \text { to } 70.0)\end{array}$ & $\begin{array}{l}22.7 \\
(13.7 \text { to } \\
35.4)\end{array}$ & $\begin{array}{l}22.0 \\
\text { (11.9 to } 37.2)\end{array}$ & $\begin{array}{l}34.8 \\
(24.4 \text { to } \\
46.8)\end{array}$ & $\begin{array}{l}38.4 \\
(29.3 \text { to } \\
48.5)\end{array}$ & $\begin{array}{l}32.5 \\
(27.8 \text { to } \\
37.6)\end{array}$ & $\begin{array}{l}45.2 \\
(41.0 \text { to } 49.4)\end{array}$ \\
\hline Brothel & $\begin{array}{l}11.8 \\
(1.7 \text { to } 5.1)\end{array}$ & $\begin{array}{l}8.0 \\
(1.2 \text { to } 39.4)\end{array}$ & $\begin{array}{l}8.3 \\
(2.4 \text { to } 25.2)\end{array}$ & $\begin{array}{l}5.3 \\
(1.6 \text { to } 16.1)\end{array}$ & $\begin{array}{l}12.4 \\
(1.9 \text { to } \\
51.5)\end{array}$ & $\begin{array}{l}8.0 \\
\text { (1.2 to } 38.3)\end{array}$ & $\begin{array}{l}19.9 \\
(4.6 \text { to } \\
55.7)\end{array}$ & $\begin{array}{l}5.9 \\
\text { (0.48 to } 44.8)\end{array}$ & 0 & 0 & 0 & 0 & $\begin{array}{l}9.8 \\
\text { (4.3 to } 21.1)\end{array}$ & $\begin{array}{l}7.5 \\
\text { (3.9 to } 13.9)\end{array}$ \\
\hline Street-based & $\begin{array}{l}46.1 \\
(32.7 \text { to } \\
60.2)\end{array}$ & $\begin{array}{l}15.7 \\
(10.3 \text { to } \\
23.4)\end{array}$ & $\begin{array}{l}36.4 \\
(28.6 \text { to } \\
45.0)\end{array}$ & $\begin{array}{l}11.2 \\
(7.3 \text { to } 16.8)\end{array}$ & $\begin{array}{l}31.0 \\
(22.4 \text { to } \\
41.3)\end{array}$ & $\begin{array}{l}19.4 \\
(13.8 \text { to } \\
26.5)\end{array}$ & $\begin{array}{l}25.3 \\
(14.7 \text { to } \\
39.8)\end{array}$ & $\begin{array}{l}11.2 \\
(3.4 \text { to } 30.9)\end{array}$ & $\begin{array}{l}59.6 \\
(46.1 \text { to } \\
71.8)\end{array}$ & $\begin{array}{l}28.9 \\
\text { (28.7 to } 50.1)\end{array}$ & $\begin{array}{l}24.8 \\
(17.2 \text { to } \\
34.4)\end{array}$ & $\begin{array}{l}20.2 \\
(12.3 \text { to } \\
31.3)\end{array}$ & $\begin{array}{l}35.7 \\
(31.2 \text { to } \\
40.4)\end{array}$ & $\begin{array}{l}16.5 \\
(12.8 \text { to } 21.0)\end{array}$ \\
\hline KK & $\begin{array}{l}29.9 \\
(21.3 \text { to } \\
40.2)\end{array}$ & $\begin{array}{l}16.5 \\
(12.4 \text { to } \\
21.7)\end{array}$ & $\begin{array}{l}14.2 \\
(10.5 \text { to } \\
18.9)\end{array}$ & $\begin{array}{l}19.2 \\
(15.0 \text { to } 24.2)\end{array}$ & $\begin{array}{l}39.2 \\
(27.1 \text { to } \\
52.8)\end{array}$ & $\begin{array}{l}21.8 \\
(15.8 \text { to } \\
29.2)\end{array}$ & $\begin{array}{l}13.4 \\
(4.1 \text { to } \\
35.8)\end{array}$ & $\begin{array}{l}10.7 \\
(6.9 \text { to } 16.1)\end{array}$ & $\begin{array}{l}5.6 \\
(2.3 \text { to } \\
12.7)\end{array}$ & $\begin{array}{l}14.8 \\
(7.9 \text { to } 25.9)\end{array}$ & $\begin{array}{l}16.3 \\
(9.6 \text { to } \\
26.4)\end{array}$ & $\begin{array}{l}18.3 \\
(13.9 \text { to } \\
23.5)\end{array}$ & $\begin{array}{l}17.9 \\
(14.4 \text { to } \\
22.0)\end{array}$ & $\begin{array}{l}16.7 \\
(14.5 \text { to } 19.1)\end{array}$ \\
\hline Other & 0 & $\begin{array}{l}16.0 \\
(10.1 \text { to } \\
24.4) \dagger\end{array}$ & 0 & $\begin{array}{l}16.0 \\
(9.6 \text { to } 25.5) \dagger\end{array}$ & 0 & $\begin{array}{l}15.9 \\
(10.4 \text { to } \\
23.5)\end{array}$ & 0 & $\begin{array}{l}12.0 \\
(6.3 \text { to } 21.8)\end{array}$ & $\begin{array}{l}12.1 \\
(7.0 \text { to } \\
20.2)\end{array}$ & $\begin{array}{l}24.4 \\
\text { (16.8 to } 34.0)\end{array}$ & $\begin{array}{l}24.1 \\
(14.9 \text { to } \\
36.7)\end{array}$ & $\begin{array}{l}23.2 \\
(16.7 \text { to } \\
31.2)\end{array}$ & $\begin{array}{l}4.1 \\
(2.5 \text { to } 6.8)\end{array}$ & $\begin{array}{l}16.7 \\
(14.1 \text { to } 19.8) \dagger\end{array}$ \\
\hline \multicolumn{15}{|l|}{$\begin{array}{l}\text { Usual method of solicitation, \% } \\
\text { (95\% Cl) }\end{array}$} \\
\hline Mediator & $\begin{array}{l}41.9 \\
(34.7 \text { to } \\
49.6)\end{array}$ & $\begin{array}{l}41.3 \\
(35.4 \text { to } \\
47.5)\end{array}$ & $\begin{array}{l}45.8 \\
(41.8 \text { to } \\
50.0)\end{array}$ & $\begin{array}{l}62.5 \\
(53.6 \text { to } 70.7)\end{array}$ & $\begin{array}{l}38.8 \\
(33.0 \text { to } \\
44.9)\end{array}$ & $\begin{array}{l}39.9 \\
(31.7 \text { to } \\
48.7)\end{array}$ & $\begin{array}{l}25.9 \\
(16.9 \text { to } \\
37.5)\end{array}$ & $\begin{array}{l}26.9 \\
(20.3 \text { to } 34.6)\end{array}$ & $\begin{array}{l}27.7 \\
(22.3 \text { to } \\
33.8)\end{array}$ & $\begin{array}{l}16.9 \\
(10.8 \text { to } 25.5)\end{array}$ & $\begin{array}{l}43.2 \\
(31.2 \text { to } \\
56.0)\end{array}$ & $\begin{array}{l}23.8 \\
(15.0 \text { to } \\
35.6)\end{array}$ & $\begin{array}{l}37.9 \\
(34.7 \text { to } \\
41.2)\end{array}$ & $\begin{array}{l}40.7 \\
(35.9 \text { to } 45.7)\end{array}$ \\
\hline Phone & $\begin{array}{l}9.4 \\
(6.6 \text { to } \\
13.3)\end{array}$ & $\begin{array}{l}15.6 \\
(10.1 \text { to } \\
23.3)\end{array}$ & $\begin{array}{l}11.6 \\
(9.6 \text { to } 14.0)\end{array}$ & $\begin{array}{l}14.7 \\
(9.1 \text { to } 22.9)\end{array}$ & $\begin{array}{l}28.0 \\
(21.6 \text { to } \\
35.4)\end{array}$ & $\begin{array}{l}33.8 \\
(28.9 \text { to } \\
30.0)\end{array}$ & $\begin{array}{l}18.5 \\
(9.5 \text { to } \\
32.9)\end{array}$ & $\begin{array}{l}48.0 \\
(33.8 \text { to } 62.6)\end{array}$ & $\begin{array}{l}32.7 \\
(25.9 \text { to } \\
40.4)\end{array}$ & $\begin{array}{l}40.8 \\
\text { (33.3 to } 48.7)\end{array}$ & $\begin{array}{l}33.2 \\
(22.8 \text { to } \\
45.6)\end{array}$ & $\begin{array}{l}35.7 \\
(29.1 \text { to } \\
42.9)\end{array}$ & $\begin{array}{l}19.5 \\
(17.0 \text { to } \\
22.2)\end{array}$ & $\begin{array}{l}29.4 \\
(24.5 \text { to } 34.9)\end{array}$ \\
\hline Public places & $\begin{array}{l}43.6 \\
(32.7 \text { to } \\
55.2)\end{array}$ & $\begin{array}{l}23.1 \\
(17.0 \text { to } \\
30.5)\end{array}$ & $\begin{array}{l}20.8 \\
(26.3 \text { to } \\
35.8)\end{array}$ & $\begin{array}{l}19.5 \\
\text { (15.7 to 23.8) }\end{array}$ & $\begin{array}{l}26.5 \\
(19.3 \text { to } \\
35.1)\end{array}$ & $\begin{array}{l}22.3 \\
(15.4 \text { to } \\
31.3)\end{array}$ & $\begin{array}{l}44.9 \\
\text { (27.6 to } \\
63.5)\end{array}$ & $\begin{array}{l}16.4 \\
(9.1 \text { to } 27.8)\end{array}$ & $\begin{array}{l}32.5 \\
(25.2 \text { to } \\
40.8)\end{array}$ & $\begin{array}{l}36.7 \\
\text { (26.7 to } 48.0)\end{array}$ & $\begin{array}{l}17.9 \\
(13.4 \text { to } \\
23.5)\end{array}$ & $\begin{array}{l}22.7 \\
(14.8 \text { to } \\
33.1)\end{array}$ & $\begin{array}{l}33.6 \\
(29.4 \text { to } \\
30.1)\end{array}$ & $\begin{array}{l}21.6 \\
\text { (18.5 to } 25.2)\end{array}$ \\
\hline Referral & $\begin{array}{l}5.1 \\
\text { (2.1 to } \\
11.7)\end{array}$ & $\begin{array}{l}20.1 \\
(14.5 \text { to } \\
27.1) \dagger\end{array}$ & $\begin{array}{l}11.8 \\
(8.8 \text { to } 15.6)\end{array}$ & $\begin{array}{l}3.3 \\
(2.2 \text { to } 5.0)+\end{array}$ & $\begin{array}{l}6.8 \\
(4.4 \text { to } \\
10.4)\end{array}$ & $\begin{array}{l}4.0 \\
\text { (2.3 to } 6.7)\end{array}$ & $\begin{array}{l}10.8 \\
(5.9 \text { to } \\
18.7)\end{array}$ & $\begin{array}{l}8.7 \\
(5.4 \text { to } 13.7) \dagger\end{array}$ & $\begin{array}{l}7.1 \\
(4.4 \text { to } \\
11.2)\end{array}$ & $\begin{array}{l}5.5 \\
\text { (2.6 to } 11.6)\end{array}$ & $\begin{array}{l}5.7 \\
\text { (4.4 to } 7.4)\end{array}$ & $\begin{array}{l}17.9 \\
(13.7 \text { to } \\
23.0) \dagger\end{array}$ & $\begin{array}{l}9.0 \\
(7.7 \text { to } 10.5)\end{array}$ & $\begin{array}{l}8.3 \\
(6.0 \text { to } 10.1) \dagger\end{array}$ \\
\hline $\begin{array}{l}\text { Monthly sex work income in Pakistani rupees, } \\
\text { median (range) }\end{array}$ & $\begin{array}{l}10000 \\
(500- \\
60000)\end{array}$ & $\begin{array}{l}10000 \\
(2000- \\
50000)\end{array}$ & $\begin{array}{l}9000 \\
(200- \\
95000)\end{array}$ & $\begin{array}{l}20000 \\
(2000- \\
90000) \dagger\end{array}$ & $\begin{array}{l}9000 \\
(17-80000)\end{array}$ & $\begin{array}{l}15000 \\
(2000- \\
80000) \dagger\end{array}$ & $\begin{array}{l}5000 \\
(300- \\
70000)\end{array}$ & $\begin{array}{l}15000 \\
(100- \\
120000) \dagger\end{array}$ & $\begin{array}{l}13000 \\
(600- \\
40000)\end{array}$ & $\begin{array}{l}25000 \\
(100- \\
150000) \dagger\end{array}$ & $\begin{array}{l}12000 \\
(20-60000)\end{array}$ & $\begin{array}{l}15000 \\
(100- \\
45000) \dagger\end{array}$ & $\begin{array}{l}9000 \\
(17-95000)\end{array}$ & $\begin{array}{l}17000 \\
(100-150000)+\end{array}$ \\
\hline $\begin{array}{l}\text { Median number of clients in last } 1 \text { month } \\
\text { (range) }\end{array}$ & $\begin{array}{l}18 \\
(2-97) \\
(\mathrm{N}=418)\end{array}$ & $\begin{array}{l}40 \\
(1-222) \dagger \\
(\mathrm{N}=370)\end{array}$ & $\begin{array}{l}21 \\
(1-800) \\
(\mathrm{N}=1189)\end{array}$ & $\begin{array}{l}70 \\
(8-270) \dagger \\
(\mathrm{N}=1125)\end{array}$ & $\begin{array}{l}5 \\
(1-500) \\
(N=373)\end{array}$ & $\begin{array}{l}25 \\
(1-200) \dagger \\
(\mathrm{N}=359)\end{array}$ & $\begin{array}{l}50 \\
(1-501) \\
(\mathrm{N}=760)\end{array}$ & $\begin{array}{l}45 \\
(7-200) \\
(N=745)\end{array}$ & $\begin{array}{l}20 \\
(1-140) \\
(\mathrm{N}=128)\end{array}$ & $\begin{array}{l}60 \\
(2-190) \dagger \\
(\mathrm{N}=330)\end{array}$ & $\begin{array}{l}20 \\
(1-70) \\
(\mathrm{N}=332)\end{array}$ & $\begin{array}{l}35 \\
(10-90) \dagger \\
(\mathrm{N}=358)\end{array}$ & $\begin{array}{l}25 \\
(1-800) \\
(\mathrm{N}=3200)\end{array}$ & $\begin{array}{l}50 \\
(1-270) \dagger \\
(\mathrm{N}=3287)\end{array}$ \\
\hline $\begin{array}{l}\text { Injected drugs in the past } 6 \text { months, \% } \\
(95 \% \mathrm{Cl})\end{array}$ & $\begin{array}{l}1.7 \\
(0.56 \text { to } \\
4.8) \\
(\mathrm{N}=423)\end{array}$ & $\begin{array}{l}5.1 \\
(3.0 \text { to } 8.5) \\
(\mathrm{N}=372)\end{array}$ & $\begin{array}{l}3.3 \\
(2.1 \text { to } 5.1) \\
(\mathrm{N}=1197)\end{array}$ & $\begin{array}{l}9.5 \\
(7.0 \text { to } 12.9) \dagger \\
(\mathrm{N}=1123)\end{array}$ & $\begin{array}{l}0.74 \\
(0.23 \text { to } \\
2.4)\end{array}$ & $\begin{array}{l}1.9 \\
(0.78 \text { to } 4.3)\end{array}$ & $\begin{array}{l}0.51 \\
(0 \text { to } 5.2) \\
(\mathrm{N}=780)\end{array}$ & $\begin{array}{l}3.2 \\
(2.1 \text { to } 4.8) \\
(\mathrm{N}=749)\end{array}$ & $\begin{array}{l}1.6 \\
(0.56 \text { to } \\
4.5) \\
(\mathrm{N}=374)\end{array}$ & $\begin{array}{l}6.9 \\
(4.4 \text { to } 10.5) \dagger \\
(\mathrm{N}=336)\end{array}$ & $\begin{array}{l}1.7 \\
(0.88 \text { to } \\
3.2) \\
(\mathrm{N}=418)\end{array}$ & $0 \dagger$ & $\begin{array}{l}1.8 \\
(1.2 \text { to } 2.7) \\
(\mathrm{N}=3595)\end{array}$ & $\begin{array}{l}5.4 \\
(4.6 \text { to } 6.3) \dagger \\
(\mathrm{N}=3324)\end{array}$ \\
\hline $\begin{array}{l}\text { In the past } 6 \text { months, had sex with a man who } \\
\text { injects drugs, \% } \\
(95 \% \mathrm{Cl})\end{array}$ & $\begin{array}{l}17.0 \\
(12.5 \text { to } \\
22.7) \\
(\mathrm{N}=424)\end{array}$ & $\begin{array}{l}7.2 \\
(5.2 \text { to } 9.9) \dagger \\
(\mathrm{N}=373)\end{array}$ & $\begin{array}{l}15.5 \\
(12.4 \text { to } \\
19.1) \\
(\mathrm{N}=1184)\end{array}$ & $\begin{array}{l}20.4 \\
(17.6 \text { to } \\
23.6) \dagger\end{array}$ & $\begin{array}{l}4.3 \\
(2.9 \text { to } 6.5) \\
(\mathrm{N}=394)\end{array}$ & $\begin{array}{l}5.6 \\
(3.4 \text { to } 8.9) \dagger\end{array}$ & $\begin{array}{l}0.13 \\
(0 \text { to } 1.3) \\
(\mathrm{N}=764)\end{array}$ & $\begin{array}{l}20.2 \\
(13.9 \text { to } \\
28.2) \dagger \\
(\mathrm{N}=749)\end{array}$ & $\begin{array}{l}3.7 \\
(2.0 \text { to } 6.7) \\
(\mathrm{N}=353)\end{array}$ & $\begin{array}{l}30.6 \\
(23.1 \text { to } \\
39.2) \dagger \\
(\mathrm{N}=340)\end{array}$ & $\begin{array}{l}7.0 \\
(4.2 \text { to } \\
11.4) \\
(\mathrm{N}=402)\end{array}$ & $\begin{array}{l}0.27 \\
(0 \text { to } 1.7) \dagger\end{array}$ & $\begin{array}{l}8.9 \\
(6.8 \text { to } 11.6) \\
(\mathrm{N}=3521)\end{array}$ & $\begin{array}{l}16.0(13.9 \text { to } \\
18.4) \dagger \\
(\mathrm{N}=3332)\end{array}$ \\
\hline
\end{tabular}




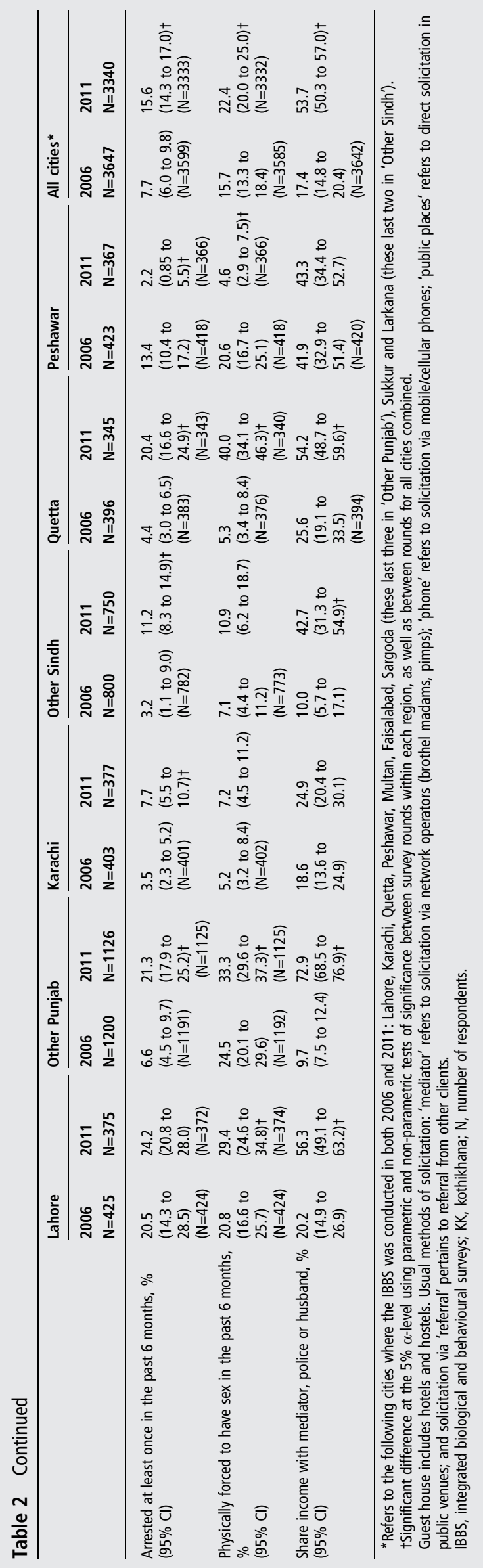

2011 likely reflect a combination of the following: improved enumeration and mapping of FSWs in $2011^{13}$ and true 'changes' in the profile and practice of FSWs in Pakistan across the nine cities. Both rounds of the IBBS were as representative as possible of the enumerated FSWs. However, limitations of mapping and enumeration of high-risk groups will limit the extent to which the surveyed participants are representative of all FSWs (including those not reached by mapping and enumeration) - a limitation common to studies of FSWs. Improvements to mapping and enumeration in 2011 suggest that compared with 2006, participants in 2011 are likely to be more representative of FSWs in their respective year. However, anecdotal and qualitative evidence suggests that sex work is on the rise in Pakistan, ${ }^{13}$ and the differences observed in sociodemographic profile as well as the practice of sex work may also reflect increased entry into sex work. Additional rounds of behavioural and biological surveillance, using repeated and enhanced enumeration (as performed in 2011), are required to better characterise the temporal dynamics, or trends, in the practice of sex work in Pakistan.

Studies among FSWs in South Asia have identified individual risk factors for HIV/STIs and associations with higher levels of condom use. ${ }^{25-28}$ In this study, more than half of FSWs reported at least one non-paying partner in the previous month. Regular, repeat or non-paying partnerships are common among FSWs in Pakistan, and such partnerships have been associated with lower rates of condom use ${ }^{26}$ and shown to be important to the sustained dynamics of STIs. ${ }^{29}$ In this study, 'always' condom use with paying partners was lower than reported in other parts of South Asia. ${ }^{26} 27{ }^{30}$ Condom use with non-paying partners is similar to that reported ${ }^{26}$ outside Pakistan, and underscores the importance of differential uptake of condoms based on the type of partnership, and the need for a different approach to increasing condom uptake during sex acts between an FSW and her non-paying partner. Anal and oral sex was common in commercial partnerships, with approximately half of FSWs engaging in non-vaginal sexual intercourse. Although few studies have questioned FSWs about providing oral sex, self-reported anal sex in the context of female sex work in Pakistan is similar to that reported in Bangladesh. ${ }^{30}$ Unprotected anal sex is associated with an increased risk of HIV transmission ${ }^{31}$ and unprotected oral sex is a mode of transmission for syphilis and gonorrhoea. Addressing protective behaviours during non-vaginal sex will be an important component for prevention of STIs and HIV in this population.

We found that FSWs faced several structural vulnerabilities, including sexual violence and arrest, despite an increasing but overall low level of contact with HIV prevention programmes as compared with districts in India. ${ }^{26}$ Obstacles to reaching FSWs in Pakistan include social conservatism and legal sanctions against commercial sex work which drive FSWs 'underground'. Sexual violence and lack of programme exposure were associated with inconsistent condom use with clients. Addressing sexual violence in this vulnerable population is an important component of an effective HIV prevention programme for women. ${ }^{10} 32$

Sixteen per cent of FSWs reported that at least one of their sexual partners in the last 6 months had injected drugs. This finding may underestimate the overlap in high-risk networks because many FSWs were unaware of the injection drug use status of their partners. However, it has been suggested that in several parts of Asia, overlap in HIV transmission networks may be important for the emergence of HIV among FSWs. ${ }^{8}$ In 2011, HIV prevalence among male IDUs in Pakistan ranged from 7.1\% in Quetta to $51.1 \%$ in Faisalabad. ${ }^{6}$ And the overlap could be 
Table 3 Individual vulnerabilities related to sexual behaviour among female sex workers in Pakistan in 2006 and 2011 for the nine cities included in both rounds of the IBBS (N=6987)

\begin{tabular}{|c|c|c|c|c|c|c|c|c|c|c|c|c|c|c|}
\hline & \multicolumn{2}{|l|}{ Lahore } & \multicolumn{2}{|c|}{ Other Punjab } & \multicolumn{2}{|l|}{ Karachi } & \multicolumn{2}{|l|}{ Other Sindh } & \multicolumn{2}{|l|}{ Quetta } & \multicolumn{2}{|l|}{ Peshawar } & \multicolumn{2}{|l|}{ All cities* } \\
\hline & $\begin{array}{l}2006 \\
N=425\end{array}$ & $\begin{array}{l}2011 \\
N=375\end{array}$ & $\begin{array}{l}2006 \\
N=1200\end{array}$ & $\begin{array}{l}2011 \\
\mathrm{~N}=1126\end{array}$ & $\begin{array}{l}2006 \\
\mathrm{~N}=403\end{array}$ & $\begin{array}{l}2011 \\
\mathrm{~N}=377\end{array}$ & $\begin{array}{l}2006 \\
\mathrm{~N}=800\end{array}$ & $\begin{array}{l}2011 \\
N=750\end{array}$ & $\begin{array}{l}2006 \\
N=396\end{array}$ & $\begin{array}{l}2011 \\
\mathrm{~N}=345\end{array}$ & $\begin{array}{l}2006 \\
\mathrm{~N}=423\end{array}$ & $\begin{array}{l}2011 \\
N=367\end{array}$ & $\begin{array}{l}2006 \\
\mathrm{~N}=3647\end{array}$ & $\begin{array}{l}2011 \\
N=3340\end{array}$ \\
\hline \multicolumn{15}{|c|}{ Condom use with clients in the last month, $\%(95 \% \mathrm{Cl})$} \\
\hline Always & $\begin{array}{l}31.0(25.8 \\
\text { to } 36.7)\end{array}$ & $\begin{array}{l}31.3(24.6 \\
\text { to } 38.8)\end{array}$ & $\begin{array}{l}11.2 \text { (8.2 to } \\
15.1)\end{array}$ & $\begin{array}{l}22.2(19.0 \text { to } \\
25.6)\end{array}$ & $\begin{array}{l}43.9(37.6 \\
\text { to } 50.4)\end{array}$ & $\begin{array}{l}48.3(41.4 \\
\text { to } 55.2)\end{array}$ & $\begin{array}{l}17.3(10.2 \\
\text { to } 28.0)\end{array}$ & $\begin{array}{l}29.1(19.5 \\
\text { to } 40.9)\end{array}$ & $\begin{array}{l}35.1(29.3 \\
\text { to } 41.3)\end{array}$ & $\begin{array}{l}39.2(32.3 \\
\text { to } 46.5)\end{array}$ & $\begin{array}{l}33.7(26.7 \\
\text { to } 41.4)\end{array}$ & $\begin{array}{l}26.9(23.1 \\
\text { to } 31.2)\end{array}$ & $\begin{array}{l}23.6(20.6 \\
\text { to } 26.7)\end{array}$ & $\begin{array}{l}30.0(26.6 \text { to } \\
33.6)\end{array}$ \\
\hline Sometimes & $\begin{array}{l}47.5(41.1 \\
\text { to } 54.0)\end{array}$ & $\begin{array}{l}42.0(34.2 \\
\text { to } 50.2)\end{array}$ & $\begin{array}{l}56.8(52.7 \\
\text { to } 60.7)\end{array}$ & $\begin{array}{l}50.8 \text { (48.9 to } \\
52.7)\end{array}$ & $\begin{array}{l}39.0(32.5 \\
\text { to } 45.8)\end{array}$ & $\begin{array}{l}41.6(34.6 \\
\text { to } 49.1)\end{array}$ & $\begin{array}{l}36.7(24.4 \\
\text { to } 51.0)\end{array}$ & $\begin{array}{l}47.9(42.2 \\
\text { to } 53.6)\end{array}$ & $\begin{array}{l}53.7(46.4 \\
\text { to } 60.9)\end{array}$ & $\begin{array}{l}35.0(28.1 \\
\text { to } 42.7)\end{array}$ & $\begin{array}{l}52.6(45.5 \\
\text { to } 59.7)\end{array}$ & $\begin{array}{l}41.8(36.1 \\
\text { to } 47.6)\end{array}$ & $\begin{array}{l}48.5(44.2 \\
\text { to } 52.7)\end{array}$ & $\begin{array}{l}45.5(43.5 \text { to } \\
47.5)\end{array}$ \\
\hline Never & $\begin{array}{l}21.5(17.9 \\
\text { to } 25.6) \\
(\mathrm{N}=423)\end{array}$ & $\begin{array}{l}26.7(18.9 \\
\text { to } 36.4) \\
(\mathrm{N}=374)\end{array}$ & $\begin{array}{l}32.1(28.1 \\
\text { to } 36.3) \\
(\mathrm{N}=1198)\end{array}$ & $\begin{array}{l}27.1(23.0 \text { to } \\
31.6) \dagger \\
(\mathrm{N}=1124)\end{array}$ & $\begin{array}{l}17.1(12.5 \\
\text { to } 23.0)\end{array}$ & $\begin{array}{l}10.1(6.9 \text { to } \\
14.4) \dagger\end{array}$ & $\begin{array}{l}46.0(26.8 \\
\text { to } 66.5) \\
(\mathrm{N}=796)\end{array}$ & $\begin{array}{l}23.1(16.1 \\
\text { to } 31.9) \dagger\end{array}$ & $\begin{array}{l}11.2(8.2 \text { to } \\
15.3) \\
(\mathrm{N}=365)\end{array}$ & $\begin{array}{l}25.8(19.5 \\
\text { to } 33.3) \dagger \\
(\mathrm{N}=337)\end{array}$ & $\begin{array}{l}13.7(9.7 \text { to } \\
18.9) \\
(\mathrm{N}=416)\end{array}$ & $\begin{array}{l}31.3(25.0 \\
\text { to } 38.5) \dagger \\
(\mathrm{N}=364)\end{array}$ & $\begin{array}{l}28.0(23.0 \\
\text { to } 33.7) \\
(\mathrm{N}=3601)\end{array}$ & $\begin{array}{l}24.5(21.8 \text { to } \\
27.5) \dagger \\
(\mathrm{N}=3326)\end{array}$ \\
\hline $\begin{array}{l}\text { Anal sex with a client in the last } \\
\text { month, } \%(95 \% \mathrm{Cl})\end{array}$ & $\begin{array}{l}11.8(8.7 \text { to } \\
15.8) \\
(\mathrm{N}=424)\end{array}$ & $\begin{array}{l}28.6(22.2 \\
\text { to } 36.1) \dagger \\
(\mathrm{N}=374)\end{array}$ & $\begin{array}{l}35.6(28.5 \\
\text { to } 43.5) \\
(\mathrm{N}=1188)\end{array}$ & $\begin{array}{l}68.2(61.9 \text { to } \\
73.9) \dagger \\
(\mathrm{N}=1125)\end{array}$ & $\begin{array}{l}12.0(8.1 \text { to } \\
17.4) \\
(\mathrm{N}=399)\end{array}$ & $\begin{array}{l}7.2(4.5 \text { to } \\
11.3)\end{array}$ & $\begin{array}{l}1.0(0.38 \text { to } \\
2.7) \\
(\mathrm{N}=793)\end{array}$ & $\begin{array}{l}52.9(43.7 \\
\text { to } 62.0) \dagger\end{array}$ & $\begin{array}{l}12.0(8.5 \text { to } \\
16.7) \\
(\mathrm{N}=341)\end{array}$ & $\begin{array}{l}77.2(70.0 \\
\text { to } 83.1) \dagger \\
(\mathrm{N}=342)\end{array}$ & $\begin{array}{l}5.2(3.6 \text { to } \\
7.5) \\
(\mathrm{N}=420)\end{array}$ & $\begin{array}{l}36.1(30.1 \\
\text { to } 42.5) \dagger \\
(\mathrm{N}=366)\end{array}$ & $\begin{array}{l}16.7(13.0 \\
\text { to } 21.0) \\
(\mathrm{N}=3565)\end{array}$ & $\begin{array}{l}50.8(45.4 \text { to } \\
56.2) \dagger \\
(\mathrm{N}=3334)\end{array}$ \\
\hline $\begin{array}{l}\text { Oral sex with a client in the last } \\
\text { month, } \%(95 \% \mathrm{Cl})\end{array}$ & $\begin{array}{l}7.4(4.7 \text { to } \\
11.3) \\
(\mathrm{N}=422)\end{array}$ & $\begin{array}{l}17.4(11.9 \\
\text { to } 24.8) \dagger \\
(\mathrm{N}=374)\end{array}$ & $\begin{array}{l}39.8(31.0 \\
\text { to } 49.3) \\
(\mathrm{N}=1191)\end{array}$ & $\begin{array}{l}66.1(61.2 \text { to } \\
70.8) \dagger \\
(\mathrm{N}=1125)\end{array}$ & $\begin{array}{l}20.0(13.6 \\
\text { to } 28.4) \\
(\mathrm{N}=400)\end{array}$ & $\begin{array}{l}20.1(15.4 \\
\text { to } 25.8) \\
(\mathrm{N}=373)\end{array}$ & $\begin{array}{l}0.38(0 \text { to } \\
2.5) \\
(\mathrm{N}=793)\end{array}$ & $\begin{array}{l}55.3(44.6 \\
\text { to } 65.5) \dagger \\
(\mathrm{N}=747)\end{array}$ & $\begin{array}{l}8.7(4.8 \text { to } \\
15.4) \\
(\mathrm{N}=333)\end{array}$ & $\begin{array}{l}49.4(39.0 \\
\text { to } 59.9) \dagger \\
(\mathrm{N}=340)\end{array}$ & $\begin{array}{l}4.1(2.5 \text { to } \\
6.6) \\
(\mathrm{N}=420)\end{array}$ & $\begin{array}{l}13.9(9.1 \text { to } \\
20.5) \dagger \\
(\mathrm{N}=361)\end{array}$ & $\begin{array}{l}17.8(13.5 \\
\text { to } 23.2) \\
(\mathrm{N}=3559)\end{array}$ & $\begin{array}{l}45.6(40.8 \text { to } \\
50.6) \dagger \\
(\mathrm{N}=3320)\end{array}$ \\
\hline $\begin{array}{l}\text { Had sex with a non-paying } \\
\text { partner in the past } 1 \text { month, \% } \\
(95 \% \text { Cl) }\end{array}$ & $\begin{array}{l}46.0(39.1 \\
\text { to } 53.0) \\
(\mathrm{N}=424)\end{array}$ & $\begin{array}{l}63.7(51.8 \\
\text { to } 74.2) \dagger\end{array}$ & $\begin{array}{l}69.8(65.6 \\
\text { to } 73.7) \\
(\mathrm{N}=1199)\end{array}$ & $\begin{array}{l}65.8(61.8 \text { to } \\
69.6)\end{array}$ & $\begin{array}{l}25.6(19.5 \\
\text { to } 32.8) \\
(\mathrm{N}=398)\end{array}$ & $\begin{array}{l}23.6(19.0 \\
\text { to } 29.0)\end{array}$ & $\begin{array}{l}39.2(16.9 \\
\text { to } 67.2) \\
(\mathrm{N}=798)\end{array}$ & $\begin{array}{l}18.9(15.6 \\
\text { to } 22.8)\end{array}$ & $\begin{array}{l}17.3(14.2 \\
\text { to } 20.8) \\
(\mathrm{N}=371)\end{array}$ & $\begin{array}{l}71.2(63.8 \\
\text { to } 77.6) \dagger \\
(\mathrm{N}=344)\end{array}$ & $\begin{array}{l}6.0(3.7 \text { to } \\
9.5) \\
(\mathrm{N}=418)\end{array}$ & $\begin{array}{l}23.7(18.1 \\
\text { to } 30.4) \dagger\end{array}$ & $\begin{array}{l}42.6(37.5 \\
\text { to } 47.8) \\
(\mathrm{N}=3608)\end{array}$ & $\begin{array}{l}46.2(40.9 \text { to } \\
51.6) \\
(\mathrm{N}=3339)\end{array}$ \\
\hline \multicolumn{15}{|c|}{ Condom use with non-paying partner in the last month } \\
\hline Always & $\begin{array}{l}21.4(15.9 \\
\text { to } 28.3)\end{array}$ & $\begin{array}{l}20.2(15.8 \\
\text { to } 25.4)\end{array}$ & $\begin{array}{l}8.7 \text { (6.4 to } \\
11.8)\end{array}$ & $\begin{array}{l}15.5 \text { (11.5 to } \\
20.6)\end{array}$ & $\begin{array}{l}21.8(14.8 \\
\text { to } 30.9)\end{array}$ & $\begin{array}{l}36.4(29.0 \\
\text { to } 44.4)\end{array}$ & $\begin{array}{l}11.0(5.2 \text { to } \\
21.5)\end{array}$ & $\begin{array}{l}15.6 \text { (7.6 to } \\
29.3)\end{array}$ & $\begin{array}{l}39.7(25.8 \\
\text { to } 55.6)\end{array}$ & $\begin{array}{l}33.5(27.4 \\
\text { to } 40.2)\end{array}$ & $\begin{array}{l}20.0 \text { (8.7 to } \\
39.5 \text { ) }\end{array}$ & $\begin{array}{l}23.0(15.0 \\
\text { to } 33.6)\end{array}$ & $\begin{array}{l}13.4(11.5 \\
\text { to } 15.7)\end{array}$ & $\begin{array}{l}20.7 \text { (18.4 to } \\
23.3)\end{array}$ \\
\hline Sometimes & $\begin{array}{l}31.1(23.2 \\
\text { to } 40.3)\end{array}$ & $\begin{array}{l}34.9(25.7 \\
\text { to } 45.3)\end{array}$ & $\begin{array}{l}34.7(29.8 \\
\text { to } 39.9)\end{array}$ & $\begin{array}{l}36.8 \text { (32.8 to } \\
41.0)\end{array}$ & $\begin{array}{l}35.5(27.1 \\
\text { to } 44.8)\end{array}$ & $\begin{array}{l}29.6(19.6 \\
\text { to } 42.0)\end{array}$ & $\begin{array}{l}29.7(16.8 \\
\text { to } 47.0)\end{array}$ & $\begin{array}{l}34.8(27.3 \\
\text { to } 43.1)\end{array}$ & $\begin{array}{l}47.4(33.5 \\
\text { to } 61.8)\end{array}$ & $\begin{array}{l}35.9(28.7 \\
\text { to } 43.9)\end{array}$ & $\begin{array}{l}32.0(12.2 \\
\text { to } 61.5)\end{array}$ & $\begin{array}{l}36.8(30.4 \\
\text { to } 43.7)\end{array}$ & $\begin{array}{l}33.9(29.8 \\
\text { to } 38.2)\end{array}$ & $\begin{array}{l}35.7 \text { (33.4 to } \\
38.2)\end{array}$ \\
\hline Never & $\begin{array}{l}47.5(39.3 \\
\text { to } 55.8) \\
(\mathrm{N}=196)\end{array}$ & $\begin{array}{l}45.0(36.2 \\
\text { to } 54.1) \\
(\mathrm{N}=238)\end{array}$ & $\begin{array}{l}56.6(51.6 \\
\text { to } 61.6) \\
(\mathrm{N}=837)\end{array}$ & $\begin{array}{l}47.7(42.1 \text { to } \\
53.4) \dagger \\
(\mathrm{N}=740)\end{array}$ & $\begin{array}{l}42.7(35.2 \\
\text { to } 50.6) \\
(\mathrm{N}=110)\end{array}$ & $\begin{array}{l}34.1(24.6 \\
\text { to } 45.1) \\
(\mathrm{N}=88)\end{array}$ & $\begin{array}{l}59.4(40.0 \\
\text { to } 76.2) \\
(\mathrm{N}=310)\end{array}$ & $\begin{array}{l}49.7(45.3 \\
\text { to } 54.0) \\
(\mathrm{N}=141)\end{array}$ & $\begin{array}{l}12.8(7.8 \text { to } \\
20.4) \\
(\mathrm{N}=78)\end{array}$ & $\begin{array}{l}30.6(24.9 \\
\text { to } 37.0) \dagger \\
(\mathrm{N}=245)\end{array}$ & $\begin{array}{l}48.0(23.0 \\
\text { to } 74.0) \\
(\mathrm{N}=25)\end{array}$ & $\begin{array}{l}40.2(29.7 \\
\text { to } 51.7) \\
(\mathrm{N}=87)\end{array}$ & $\begin{array}{l}52.7(47.7 \\
\text { to } 57.6) \\
(\mathrm{N}=1556)\end{array}$ & $\begin{array}{l}43.5(40.9 \text { to } \\
46.2) \dagger \\
(\mathrm{N}=1539)\end{array}$ \\
\hline HIV prevalence,§ \% (95\% Cl) & 0 & $\begin{array}{l}0.53(0.16 \\
\text { to } 1.8)\end{array}$ & 0 & $\begin{array}{l}0.18 \text { (0 to } \\
0.71)\end{array}$ & 0 & $\begin{array}{l}1.9(0.90 \text { to } \\
3.8)\end{array}$ & 0 & $\begin{array}{l}1.3 \text { (0.65 to } \\
2.7 \text { ) }\end{array}$ & 0 & 0 & 0 & 0 & 0 & $\begin{array}{l}0.63 \text { (0.43 to } \\
0.92)\end{array}$ \\
\hline
\end{tabular}

${ }^{*}$ Refers to the following cities where the IBBS was conducted in both 2006 and 2011: Lahore, Karachi, Quetta, Peshawar, Multan, Faisalabad, Sargoda (these last three in 'Other Punjab'), Sukkur and Larkana (these last two in 'Other Sindh').

tSignificant difference at the $5 \% \alpha$-level using parametric and non-parametric tests of significance between survey rounds and within each region, as well as between rounds for all cities combined.

†Condom use among FSWs who had sex with a non-paying partner in the previous month.

SHIV prevalence was not compared between rounds.

FSW, female sex worker; IBBS, integrated biological and behavioural surveys; KK, kothikhana; $\mathrm{N}$, number of respondents. 
Table 4 Factors associated with inconsistent condom use with clients ( $N=4282)$ and non-paying partners ( $N=2276)$, and increased HIV prevalence ( $\mathrm{N}=2838)$ among Pakistani female sex workers in 2011 across 12 cities

\begin{tabular}{|c|c|c|c|c|c|c|}
\hline \multirow[b]{2}{*}{ Characteristic } & \multicolumn{2}{|c|}{$\begin{array}{l}\text { Inconsistent condom use with } \\
\text { clients in the last month } \\
(\mathrm{N}=3179)\end{array}$} & \multicolumn{2}{|c|}{$\begin{array}{l}\text { Inconsistent condom use with } \\
\text { non-commercial partners in } \\
\text { the last month }(\mathrm{N}=1896)\end{array}$} & \multicolumn{2}{|c|}{ HIV positive* $(\mathrm{N}=25)$} \\
\hline & $\begin{array}{l}\text { Adjusted OR } \\
(95 \% \mathrm{CI})\end{array}$ & p Value & $\begin{array}{l}\text { Adjusted OR } \\
(95 \% \mathrm{CI})\end{array}$ & p Value & $\begin{array}{l}\text { Adjusted OR } \\
(95 \% \mathrm{CI})\end{array}$ & p Value \\
\hline Illiterate (unable to read/write) & 1.8 (1.4 to 2.2$)$ & $<0.001$ & 1.9 (1.4 to 2.7$)$ & $<0.001$ & - & - \\
\hline \multicolumn{7}{|l|}{ Duration in sex work } \\
\hline$<2$ years & Ref & & Ref & & - & - \\
\hline$\geq 2$ years & 1.5 (1.1 to 1.9$)$ & 0.004 & 1.7 (1.1 to 2.4$)$ & 0.009 & & \\
\hline \multicolumn{7}{|l|}{ Usual method of solicitation } \\
\hline Mediator & Ref & & Ref & & - & - \\
\hline Phone & $0.73(0.57$ to 0.93$)$ & 0.01 & $0.70(0.47$ to 0.97$)$ & 0.04 & & \\
\hline Public places & 0.62 (0.47 to 0.82 ) & 0.001 & 0.59 (0.42 to 0.82$)$ & 0.002 & & \\
\hline Referral & 0.62 (0.46 to 0.84$)$ & 0.002 & $0.55(0.34$ to 0.88$)$ & 0.02 & & \\
\hline \multicolumn{7}{|l|}{ Number of clients per month } \\
\hline$<60$ & - & - & Ref & & - & - \\
\hline$\geq 60$ & & & $1.5(1.2$ to 1.8$)$ & 0.001 & & \\
\hline Have a non-commercial partner in the last 1 month & $1.5(1.1$ to 1.9$)$ & 0.005 & - & - & - & - \\
\hline Injected drugs in the previous 6 months & - & - & - & - & 4.7 (1.1 to 19.6$)$ & 0.04 \\
\hline \multicolumn{7}{|c|}{ In the past 6 months, had sex with a man who injects drugs } \\
\hline No & Ref & & - & - & - & - \\
\hline Yes & $1.7(1.2$ to 2.3$)$ & 0.001 & & & & \\
\hline Don't know & $1.6(1.2$ to 2.0$)$ & $<0.001$ & & & & \\
\hline Experienced sexual violence in the previous 6 months & $1.4(1.1$ to 1.7$)$ & 0.01 & $1.4(1.1$ to 1.9$)$ & 0.04 & & \\
\hline Has not accessed prevention programmes for FSWs & $3.2(2.2$ to 4.4$)$ & $<0.001$ & 1.9 (1.3 to 2.8$)$ & 0.003 & 7.5 (1.5 to 39.1$)$ & 0.02 \\
\hline \multicolumn{7}{|l|}{ Region } \\
\hline Lahore & Ref & & Ref & & $\dagger$ & - \\
\hline Other Punjab & $1.9(1.4$ to 2.8$)$ & $<0.001$ & 1.6 (1.0 to 2.6$)$ & 0.05 & & \\
\hline Karachi & $0.71(0.45$ to 1.1$)$ & 0.1 & $0.56(0.33$ to 0.96$)$ & 0.03 & & \\
\hline Other Sindh & $1.9(1.2$ to 3.1$)$ & 0.008 & $1.6(0.75$ to 3.4$)$ & 0.2 & & \\
\hline Quetta & $0.69(0.40$ to 1.2$)$ & 0.2 & 0.57 (0.33 to 0.99$)$ & 0.05 & & \\
\hline Peshawar & 1.5 (1.0 to 2.2 ) & 0.05 & 0.95 (0.49 to 1.8$)$ & 0.9 & & \\
\hline Haripur & $1.6(0.83$ to 3.1$)$ & 0.2 & 2.4 (1.5 to 3.8$)$ & 0.001 & & \\
\hline \multicolumn{7}{|c|}{$\begin{array}{l}\text { *For HIV prevalence, only regions in which at least one case of HIV was detected were included for analysis (Lahore, Other Punjab, Karachi, Other Sindh, Haripur). The adjusted ORs for } \\
\text { each covariate associated with HIV prevalence were only adjusted for region. } \\
\text { tAdjusted ORs are not shown for region although region is included in the adjusted ORs for each of the following covariates separately: 'has not accessed prevention programmes for } \\
\text { FSWs' and 'injected drugs in the previous } 6 \text { months'. } \\
\text { Usual methods of solicitation: 'mediator' refers to solicitation via network operators (brothel madams, pimps); 'phone' refers to solicitation via mobile/cellular phones; 'public places' } \\
\text { refers to direct solicitation in public venues; and solicitation via 'referral' pertains to referral from other clients. } \\
\text { Inconsistent condom use refers to self-reported 'sometimes' or 'never' condom use in the month preceding the survey. Note that covariate 'typology' was not included in the regression } \\
\text { model development because of correlation with 'usual method of solicitation'. For outcomes relating to condom use, all } 12 \text { cities were included, and the adjusted ORs from the final } \\
\text { regression model are shown. } \\
\text { FSW, female sex worker. }\end{array}$} \\
\hline
\end{tabular}

caused by the fraction of FSWs who inject drugs and share needles, and also through sex between FSWs and IDUs. We found that recent injection drug use was associated with HIV-positivity in FSWs, although this association was based on a small number of HIV-positive FSWs and a small number of FSWs who report recent injecting behaviour. Despite this association, a considerable fraction of HIV-positive cases could not be attributed to recent injection drug use: 22 of the $25 \mathrm{HIV}$-positive FSWs denied having injected drugs in the past 6 months. Reports of injection drug use among sexual partners is expected to be less reliable than reporting one's own injection history. Although our survey did not include data on injecting behaviour in the remote past, the above finding suggests that HIV may be emerging among FSWs as a result of sexual transmission from networks with higher HIV prevalence, such as IDUs and high-risk men who have sex with men. Further study into the intersection of sex work and injection drug use in Pakistan, including the role of mediators (of paid sex and/or drugs), is needed.
Our findings are limited by the serial cross-sectional nature of the study, our inability to track individuals who were interviewed in both rounds, and therefore, the restrictions placed on interpreting differences in sexual behaviour and HIV risk over time. Enumeration and mapping improved in 2011. Hence, study samples could represent different FSW populations in the two survey rounds, which is a limitation of the comparison between FSWs in 2006 and FSWs in 2011. The overall ('all cities') comparison between 2006 and 2011 is also limited by the absence of proportional weighting for cities by FSW population size. An unweighted descriptive analysis was performed because the comparison between survey rounds reflects the nine cities included in both surveys, and was not intended to be representative of the whole country. The comparison between 2006 and 2011, therefore, is restricted to the nine cities included for analysis. The surveys are also conducted in the context of a surveillance programme, and therefore, detailed questions related to individual and structural vulnerabilities are limited to the 


\section{Key messages}

- HIV may be emerging among female sex workers (FSWs) in Pakistan, where FSWs remain vulnerable to HIV and access to HIV prevention programmes remains low.

- Exposure to HIV prevention programmes is associated with protective behaviours (condom use with clients) and the absence of HIV.

- Overlap with injection drug use through sexual partners' injecting behaviour or FSWs' injecting behaviour is associated with lower levels of condom use and HIV, respectively.

- Adaptive HIV prevention strategies are needed to increase programme access and to address the intersection of vulnerable sexual networks and injecting drug use.

level of detail presented in this study (ie, a general overview). Nonetheless, important differences in vulnerabilities were detected between 2006 and 2011, and risk profiling of FSWs least likely to consistently use condoms with clients and nonpaying partners will help prevention programmes focus on the most vulnerable FSWs. The emergence of HIV and overlap with intersecting sexual and injecting networks requires further study, and underscores the importance of addressing HIV risk in connected high-risk groups in Pakistan.

Acknowledgements We thank the Canada-Pakistan HIVIAIDS Surveillance Project (HASP) team for their efforts in mapping, data collection, specimen collection, data entry and knowledge translation. We also thank study participants for their time and willingness to answer sensitive questions. We thank Dr Tahira Reza (HASP) for her assistance with data management.

Contributors JFB conceived of the study, designed the analyses, interpreted results and critically reviewed the manuscript. SM designed and performed the analyses, interpreted results, drafted the manuscript and contributed to manuscript revisions. LHT contributed to study conception, planning of analyses, manuscript writing, manuscript revisions and interpretation of results, and co-ordinated the study. FE conducted the surveillance project, led data collection, developed the questionnaires, contributed to study conception and critically reviewed the manuscript. AS and NK contributed to the surveillance project and data collection, and critically reviewed the manuscript.

Funding This study (the Canada-Pakistan HIV/AIDS Surveillance Project) was funded by the Canadian International Development Agency (CIDA PK 30849). SM is supported by a Canadian Institutes of Health Research Fellowship and a Royal College of Physicians and Surgeons of Canada Detweiler Traveling Fellowship.

\section{Competing interests None.}

Ethics approval HOPE International in Pakistan and the Public Health Agency of Canada approved this study.

Provenance and peer review Commissioned; externally peer reviewed.

Open Access This is an Open Access article distributed in accordance with the Creative Commons Attribution Non Commercial (CC BY-NC 3.0) license, which permits others to distribute, remix, adapt, build upon this work non-commercially, and license their derivative works on different terms, provided the original work is properly cited and the use is non-commercial. See: http://creativecommons.org/licenses/by-nc/3.0/

\section{REFERENCES}

1 Saeed F. Taboo! The hidden culture of a red light area. Oxford: Oxford University Press, 2002.

2 Brown L. The dancing girls of Lahore: selling love and saving drams in Pakistan's ancient pleasure district. New York: Harper Collins Publishers, 2005.

3 Emmanuel F, Blanchard J, Zaheer HA, et al. The HIVIAIDS surveillance project mapping approach: an innovative approach for mapping and size estimation for groups at a higher risk of HIV in Pakistan. AIDS 2010;24(Suppl 2):S77-84.

4 Emmanuel F, Thompson LH, Athar U, et al. The organization, operational dynamics and structure of female sex work in Pakistan. Sex Transm Infect 2013.

5 Nagelkerke N, Moses S, de Vlas SJ, et al. Modelling the public health impact of male circumcision for HIV prevention in high prevalence areas in Africa. BMC Infect Dis 2007;7:16.
6 Archibald CP, Shaw SY, Emmanuel F, et al. Geographic and temporal variation of injection drug users in Pakistan. Sex Transm Infect 2013;89:ii18-28.

7 Khan MS, Unemo M, Zaman S, et al. HIV, STI prevalence and risk behaviours among women selling sex in Lahore, Pakistan. BMC Infect Dis 2011;11:119.

8 Bokhari A, Nizamani NM, Jackson DJ, et al. HIV risk in Karachi and Lahore, Pakistan: an emerging epidemic in injecting and commercial sex networks. Int J STD AIDS 2007;18:486-92.

9 Blanchard JF, Khan A, Bokhari A. Variations in the population size, distribution and client volume among female sex workers in seven cities of Pakistan. Sex Transm Infect 2008;84:II24-7.

10 Beattie TSH, Bhattacharjee P, Ramesh BM, et al. Violence against female sex workers in Karnataka state, south India: impact on health, and reductions in violence following an intervention program. BMC Public Health 2010;10:476.

11 Swain SN, Saggurti N, Battala M, et al. Experience of violence and adverse reproductive health outcomes, HIV risks among mobile female sex workers in India. BMC Public Health 2011;11:357.

12 Moses S, Blanchard JF, Kang H, et al. AIDS in South Asia: understanding and responding to a heterogenous epidemic. Washington: The World Bank, 2006.

13 Pakistan National AIDS Control Program and Canada-Pakistan HIV/AIDS Surveillance Project. HIV second generation surveillanace in Pakistan: national report round 4. Islamabad, 2011. http://www.nacp.gov.pk/surveillance_and_research/ (accessed 20 Nov 2012).

14 Pakistan National AIDS Control Program. HIV Second Generation Surveillance in Pakistan—Round 2. Islamabad, 2007. http://www.nacp.gov.pk/library/reports/ (accessed 25 Jun 2012).

15 Pakistan National AIDS Control Program and Canada-Pakistan HIVIAIDS Surveillance Project. Pakistan high-risk groups mapping report. Islamabad, 2011. http://www. nacp.gov.pk/surveillance_and_research/(accessed 20 Nov 2012).

16 Family Health International. Behavioral surveillance surveys: guidelines for repeated behavioral surveys in populations at risk of HIV. 2000. http://www.fhi360.org/en/ HIVAIDS/pub/guide/bssguidelines.htm (accessed 22 Nov 2012).

17 Irfan M. Pakistan's wage structure during 1990/91-2006/07. Pakistan Institute of Development Economics Islamabad, Pakistan, 2008.

18 Fung $\mathrm{ICH}$, Guinness L, Vickerman P, et al. Modelling the impact and cost-effectiveness of the HIV intervention programme amongst commercial sex workers in Ahmedabad, Gujarat, India. BMC Public Health 2007;7:195.

19 Kumar S. A rapid situation assessment of sexual risk behaviour and substance use among sex workers and their clients in Chennai (Madras), South India. Geneva, Switzerland: World Health Organization, 2003.

20 Shahmanesh $M$, Wayal $S$, Andrew $G$, et al. HIV prevention while the bulldozers roll: Exploring the effect of the demolition of Goa's red-light area. Soc Sci Med 2009;69:604-12.

21 Ananthaswamy A. Cellphones get help to India's secret sex workers. New Sci 2011;2809:21-22.

22 Curioso WH, Karras BT, Campos PE, et al. Design and implementation of Cell-PREVEN: a real-time surveillance system for adverse events using cell phones in Peru. AMIA Annu Symp Proc 2005;2005:176-80.

23 UNAIDS. Preventing HIV with social media and mobile phones. http://www.unaids. org/en/resources/presscentre/featurestories/2011/may/20110502sm/

24 World Bank. World Bank Database. http://data.worldbank.org/indicator/NY.GDP. DEFL.KD.ZG (accessed 20 Nov 2012).

25 Reza-Paul S, Beattie T, Syed HUR, et al. Declines in risk behaviour and sexually transmitted infection prevalence following a community-led HIV preventive intervention among female sex workers in Mysore, India. AIDS 2008;22(Suppl 5): S91-100.

26 Ramesh BM, Beattie TSH, Shajy l, et al. Changes in risk behaviours and prevalence of sexually transmitted infections following HIV preventive interventions among female sex workers in five districts in Karnataka state, south India. SexTransm Infect 2010;86(Suppl 1):i17-24.

27 Ramesh BA, Moses S, Washington R, et al. Determinants of HIV prevalence among female sex workers in four south Indian states: analysis of cross-sectional surveys in twenty-three districts. AIDS 2008;22(Suppl 5):S35-44.

28 Mondal NI, Hossain K, Islam R, et al. Sexual behavior and sexually transmitted diseases in street-based female sex workers in Rajshahi City, Bangladesh. Braz J Infect Dis 2008;12:287-92.

29 Watts C, Zimmerman C, Foss AM, et al. Remodelling core group theory: the role of sustaining populations in HIV transmission. Sex Transm Infect 2010;86(Suppl 3): iii85-92.

30 Islam MM, Conigrave KM. HIV and sexual risk behaviors among recognized high-risk groups in Bangladesh: need for a comprehensive prevention program. Int $J$ Infect Dis 2008;12:363-70.

31 Baggaley RF, White RG, Boily M-C. HIV transmission risk through anal intercourse: systematic review, meta-analysis and implications for HIV prevention. Int I Epidemiol 2010;39:1048-63.

32 Watts $\mathrm{CH}$, Foss AM, Hossain M, et al. Sexual violence and conflict in Africa: prevalence and potential impact on HIV incidence. Sex Transm Infect 2010; 86(Suppl 3):iii93-9. 